TITLE:

\title{
Three new species of Leptolalax from Thailand (Amphibia, Anura, Megophryidae)
}

$\operatorname{AUTHOR}(S)$ :

Matsui, Masafumi

CITATION:

Matsui, Masafumi. Three new species of Leptolalax from Thailand

(Amphibia, Anura, Megophryidae). Zoological Science 2006, 23(9): 821830

ISSUE DATE:

2006-09

URL:

http://hdl.handle.net/2433/65033

RIGHT:

(c) 日本動物学会 / Zoological Society of Japan 


\title{
Three New Species of Leptolalax from Thailand (Amphibia, Anura, Megophryidae)
}

\author{
Masafumi Matsui ${ }^{\star}$ \\ Graduate School of Human and Environmental Studies, Kyoto University, \\ Sakyo-ku, Kyoto 606-8501, Japan
}

\begin{abstract}
Three new megophryid species, Leptolalax melanoleucus, L. fuliginosus, and L. solus, are described from southwestern and southern Thailand on the bases of acoustic and morphological characteristics. Leptolalax melanoleucus and $L$. fuliginosus are similar to $L$. pelodytoides from northern Thailand, but differ from it completely in advertisement call characteristics and ventral color. Leptolalax solus is similar to $L$. heteropus from peninsular Malaysia, but differs from it by advertisement call, as well as by some body proportions. The distributional pattern of Leptolalax within Thailand is discussed.
\end{abstract}

Key words: acoustics, Leptolalax, new species, Southeast Asia, taxonomy, zoogeography

\section{INTRODUCTION}

The number of known species in the Southeast Asian megophryid genus Leptolalax has rapidly increased in the last three decades (Dubois, 1983, 1987; Fei et al., 1991; Fei and Ye, 1992; Malkmus, 1992; Matsui, 1997; Inger et al., 1997, 1999; Lathrop et al, 1998; Ohler et al., 2000; Grismer et al., 2004). Analyses of call characteristics, recently added to traditional morphological methods in conducting taxonomic studies on frogs, played an important role in detecting some cryptic members in this genus (Malkmus and Riede, 1993; Matsui, 1997).

Two species of Leptolalax, L. pelodytoides (Boulenger, 1893) and L. minimum (Taylor, 1962), have traditionally been recognized in the northern and northeastern parts of Thailand, respectively (Taylor, 1962), although the latter species is now generally treated as a synonym of the former (Dubois, 1983, but see Discussion). The occurrence of congeners in the more southern region of the country, though briefly referred to by Chan-ard (2003), is not well documented.

During our field survey in Thailand, I collected many Leptolalax specimens, mainly along the western border of the country. Specimens from the northern region were tentatively identified as $L$. pelodytoides on the basis of examination of its types. They were basically similar in acoustic characteristics (Matsui, unpublished data). In contrast, specimens collected from more southern regions had calls that sound quite different from the northern $L$. pelodytoides to the human ear. Detailed analyses of acoustic and morphological characters have proved that there are three distinct forms that are different from $L$. pelodytoides. In this paper, I describe these three species as new to science.

\footnotetext{
${ }^{*}$ Corresponding author. Phone: $+81-75-753-6846$; Fax : +81-75-753-6846; E-mail: fumi@zoo.zool.kyoto-u.ac.jp
}

\section{MATERIALS AND METHODS}

I collected Leptolalax or ascertained its occurrence without collection in northeastern (Loei Province), northern (Mae Hong Son and Chiang Mai Provinces), southwestern (Kanchanaburi and Prachuap Khiri Khan Provinces), and southern (Surat Thani and Narathiwat provinces) Thailand during my field surveys in various localities of this country between 1994 and 2004 (regional divisions following Nabhitabhata et al., 2000). I failed to find specimens of this genus in other parts of Thailand.

I made recordings of calls in the field using a cassette tape recorder (Sony TC-D5) with an external microphone (Sony ECM23). At the time of recording, I made temperature measurements using a quick-recording thermistor thermometer (Takara A 600). I analyzed the recorded calls using the computer programs SoundEdit Vers. 2 or SoundEdit Pro (MacroMind-Paracomp, Inc.) on a Macintosh computer. Methods of analyses are as described elsewhere (Matsui, 1997).

After recording calls, I collected specimens, took tissues for subsequent biochemical analysis, and fixed the specimens for vouchers. Specimens, fixed in $10 \%$ formalin and later preserved in $70 \%$ ethanol, are stored at the Chulalongkorn University Zoological Museum (CUZM) and the Graduate School of Human and Environmental Studies, Kyoto University (KUHE). Sixteen body measurements were taken, mainly following Matsui $(1984,1997)$ : 1) snoutvent length (SVL); 2) head length (HL); 3) snout length (SL); 4) eye length (EL, including eyelid); 5) tympanum-eye length (T-EL); 6) tympanum diameter (TD); 7) head width (HW); 8) internarial distance (IND); 9) interorbital distance (IOD); 10) upper eyelid width (UEW); 11) lower arm length (LAL); 12) inner palmar tubercle length (IPTL); 13) tibia length (TL); 14) foot length (FL); 15) hindlimb length $(\mathrm{HLL}) ; 16)$ inner metatarsal tubercle length (IMTL). I made all measurements to the nearest $0.1 \mathrm{~mm}$ with dial calipers under a binocular dissecting microscope. The system of description of toe-webbing states follows that used by Savage (1975).

For comparisons, I examined specimens of Leptolalax stored at the Field Museum of Natural History, Chicago (FMNH); KUHE; Museo Civico di Storia Naturale, Genova (MSNG); Museum National d'Histoire Naturelle, Paris (MNHNP); Natural History Museum, London (BM); Sabah Parks, Kota Kinabalu (SP); Universiti Malaysia Sabah, Kota Kinabalu (BORNEENSIS collection of UMS); Zoologisches Museum, Universität Humboldt, Berlin (ZMB); 
and Institut Royal des Sciences Naturelles de Belgique (IRSNB) (see Appendix 1).

\section{SYSTEMATICS}

Leptolalax melanoleucus sp. nov.

(Fig. 1A, B)

\section{Diagnosis}

A medium-sized form of the genus Leptolalax; male 26.6-28.8 mm ( $n=13)$, female $32.7 \mathrm{~mm}(\mathrm{n}=1) \mathrm{SVL}$; tibiotarsal articulation usually reaching between eye and nostril; similar to $L$. pelodytoides, but with much lower dominant frequency of advertisement call of 3050 to $3200 \mathrm{hz}$; differing from all congeners by unique ventral coloration, with large black markings on a white background.

\section{Etymology}

The specific epithet is from Greek meaning black and white, in reference to the contrasting ventral marking of the new species.

\section{Holotype}

KUHE 19720, an adult male from Khlong Saeng Wildlife Sanctuary, Surat Thani Province, Thailand $\left(9^{\circ} 15^{\prime} \mathrm{N}, 98^{\circ} 39^{\prime}\right.$ E), collected on 29 August 1995 by Masafumi Matsui.

\section{Paratypes}

CUZM (A) 5270-5272; KUHE 19694, 19724, 19732 (six males); all collected between 28 and 29 August 1995 from the same locality as the holotype by Masafumi Matsui and Hidetoshi Ota.

\section{Referred specimens}

CUZM (A) 5273, 5274, KUHE 23820, 23844 (four males), 23845 (one female) from Khao Sok National Park, Surat Thani Province, Thailand $\left(9^{\circ} 00^{\prime} \mathrm{N}, 98^{\circ} 38^{\prime} \mathrm{E}\right)$, collected 19-20 August 1997 by Masafumi Matsui; KUHE 35081 (one male) from Pilok, Thong Pha Pum, Kanchanaburi Province, Thailand (14 $\left.49^{\prime} \mathrm{N}, 98^{\circ} 31^{\prime} \mathrm{E}\right)$, collected on 3 January 2002 by Masafumi Matsui and Wichase Khonsue; IRSNB-KBIN 13243 (one male) from Klong Hat Som Pen, Muang, Ranong Province, Thailand ( $9^{\circ} 57^{\prime} \mathrm{N}, 98^{\circ} 41^{\prime}$ E), collected on 1 September 2003 by O. S. G. Pauwels, C. Chimsunchart, and M. Sumontha.

\section{Description of holotype (measurements in $\mathrm{mm}$ )}

SVL 28.6; habitus moderately stocky; head longer (11.3) than broad (10.2); snout rounded, truncate in profile, projecting slightly beyond lower jaw; eye diameter (4.4) slightly greater than snout length (4.1); canthus distinct, slightly constricted; lore slightly oblique, slightly concave; nostril lateral, below canthus, distinctly closer to tip of snout than to eye; internarial distance (2.7) narrower than interorbital distance (3.3), latter subequal to upper eyelid (3.3); pineal spot absent; tympanum distinct, diameter (2.1) about half that of eye, and separated from eye by one-third of tympanic diameter (0.8); vomerine teeth absent; tongue notched, without papillae; a median, subgular vocal sac in the mid-ventral line; vocal openings posterior to rictus, close to eustachian tube openings.

Forelimb slender; fingers slender, unwebbed, first finger slightly shorter than second, latter slightly shorter than fourth; tips slightly swollen; inner palmar tubercle large (1.4), not extending onto first metacarpal and smaller outer palmar tubercle; subarticular tubercles indistinct, replaced by indistinct callous tissue; nuptial pads absent.

Hindlimb relatively long (45.5); tibia relatively long (14.0), heels slightly overlapping when limbs are held at right angles to body; tibiotarsal articulation of adpressed limb reaching between eye and nostril; foot (12.3) shorter than tibia; third toe longer than fifth; toe tips similar to those of fingers; webbing confined to bases of toes (Fig. 2A), formula: I $1^{2 / 3}-2+|| 1^{4} / 5-3$ III $2^{2} / 3-3^{4} / 5$ IV $4-2^{2} / 3 \mathrm{~V}$; toes without lateral fringes; subarticular tubercles obscure, but elongate, replaced by low keratinous dermal ridges, a relatively short one on each of second, third, and fifth toes, larger ones on fourth toe; inner metatarsal tubercle low, length (1.0) less than half of first toe; no outer metatarsal tubercle.

Skin nearly smooth, scattered with small tubercles of varying sizes above; eyelid and top of snout without tubercles; a low, supratympanic ridge from eye to above axilla; sides with larger tubercles; chest and abdomen smooth; small, weak pectoral gland, femoral gland indistinct; a small, round, white gland above axilla; large glands anterior to sides of vent; ventrolateral glandular ridges indistinct; skin of gular region not modified.

\section{Color in life}

Olive brown dorsally on head and body, with indistinct dark brown markings, including interorbital one; tympanum masked black; no spot on canthus; lips barred with black; sides with small dark spots; groin with dark spot extending onto anterior half of thigh; large glands anterior to sides of vent white; limbs marked dorsally with alternating olive and dark brown crossbars; dark bar restricted to posterior side around the elbow, between upper and lower arms; sides of tibia with black spots, continuous as bars across dorsal surface; chin and throat white with dark brown vermiform lines; chest and abdomen white mottled with large, continuous black markings; ventral and posterior surfaces of thigh dark brown with few white spots; iris orange on upper half, silver reticulated with black on lower half.

\section{Color in preservative}

In preservative, color and pattern have not obviously changed, though they have generally faded. The dorsal coloration has slightly faded to grey-brown, and upper and lower halves of iris have become indistinguishable.

\section{Eggs}

The single female from Khao Sok released part of her eggs in a plastic container soon after collection. The diameter of 10 ova ranged from 1.38-1.57 (mean $\pm 2 \mathrm{SE}=1.51 \pm$ $0.03) \mathrm{mm}$. Both animal and vegetal poles were uniformly cream in color.

\section{Call characteristics}

Calls were recorded at Khlong Saeng on 29 August 1995 at a ground temperature of $23.9^{\circ} \mathrm{C}$. They consisted of a long series of notes, each composed of three to four indistinct pulses and lasting 40-63 ms (Fig. 3A). During active calling, the note-gap and note-repetition rates varied greatly, but were mostly $102-180 \mathrm{~ms}$ and about 6.1 per s, respec- 


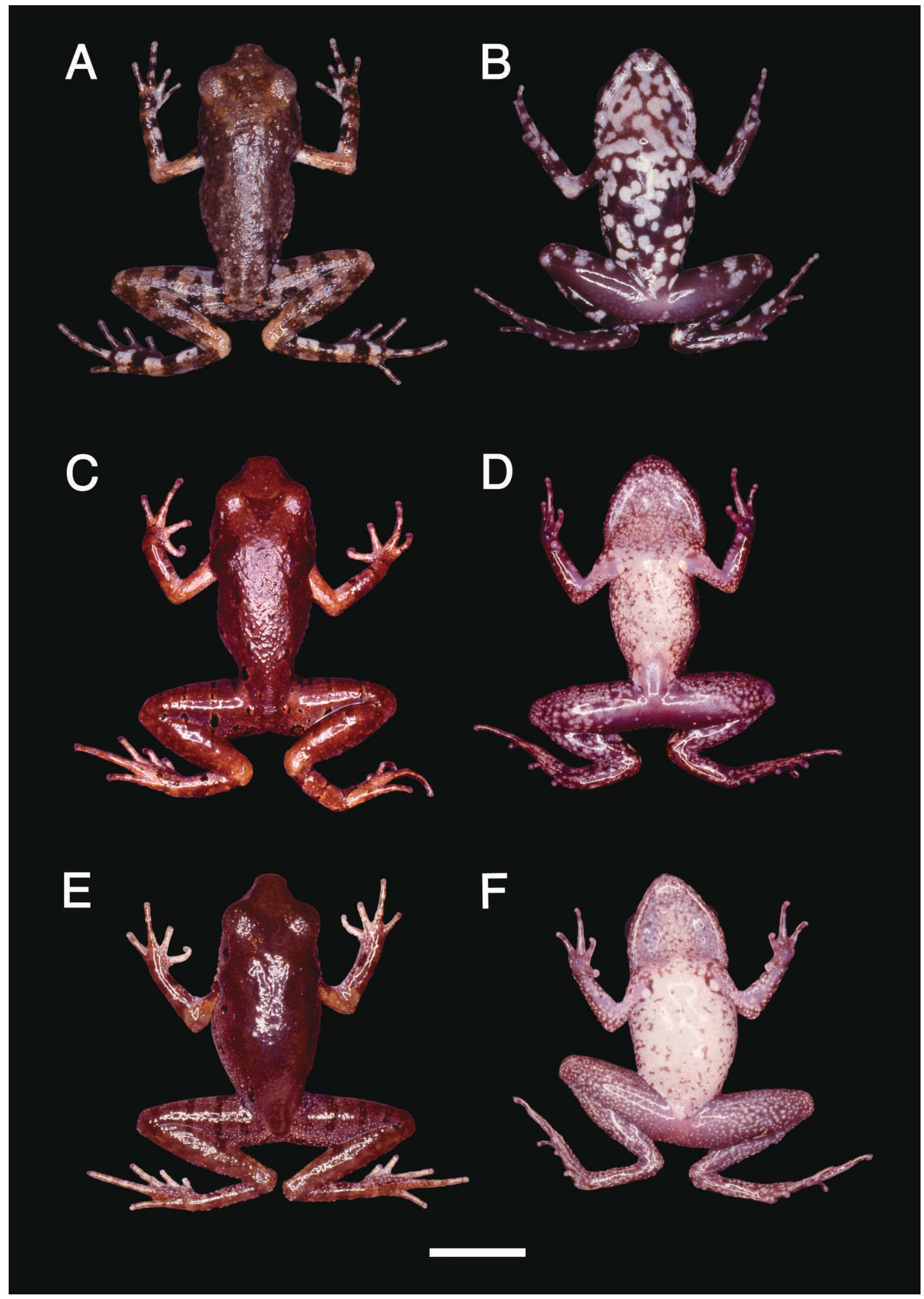

Fig. 1. Male holotypes of (A, B) Leptolalax melanoleucus (KUHE 19720), (C, D) L. fuliginosus (KUHE 20174), and (E, F) L. solus (KUHE 23261); dorsal (A, C, E) and ventral views (B, D, F). Scale bar $=10 \mathrm{~mm}$. 

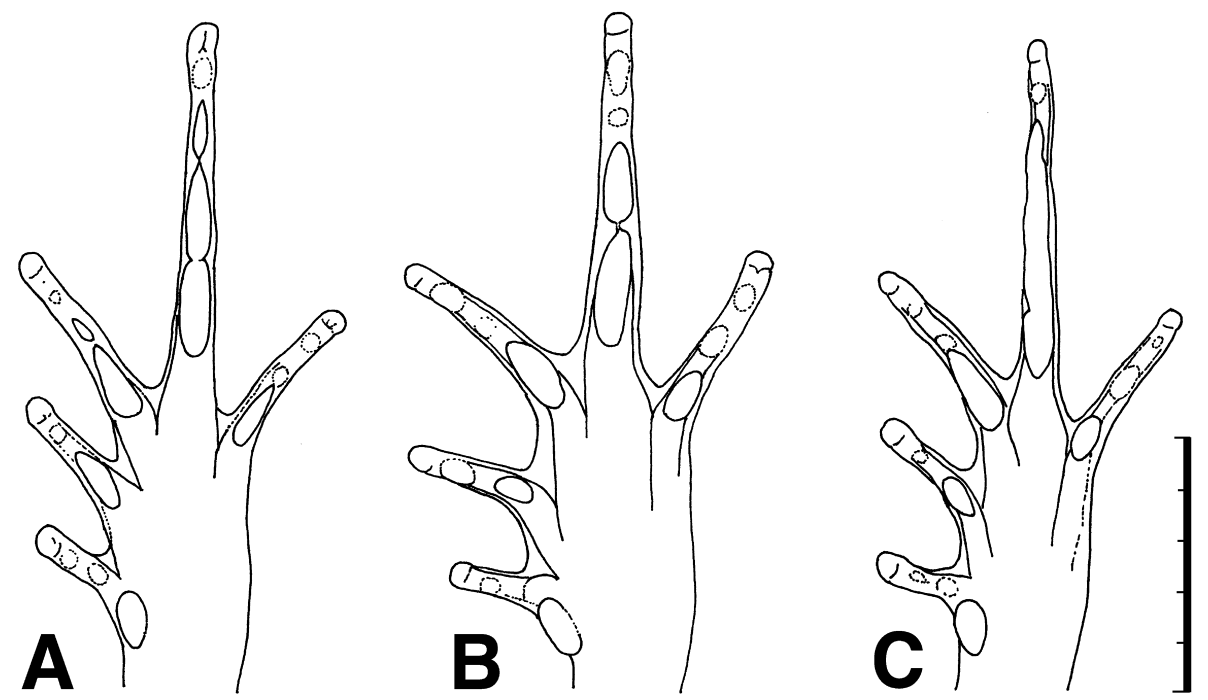

Fig. 2. Left feet of holotypes of (A) Leptolalax melanoleucus, (B) L. fuliginosus, and (C) L. solus; ventral views. Scale bar=5 mm.

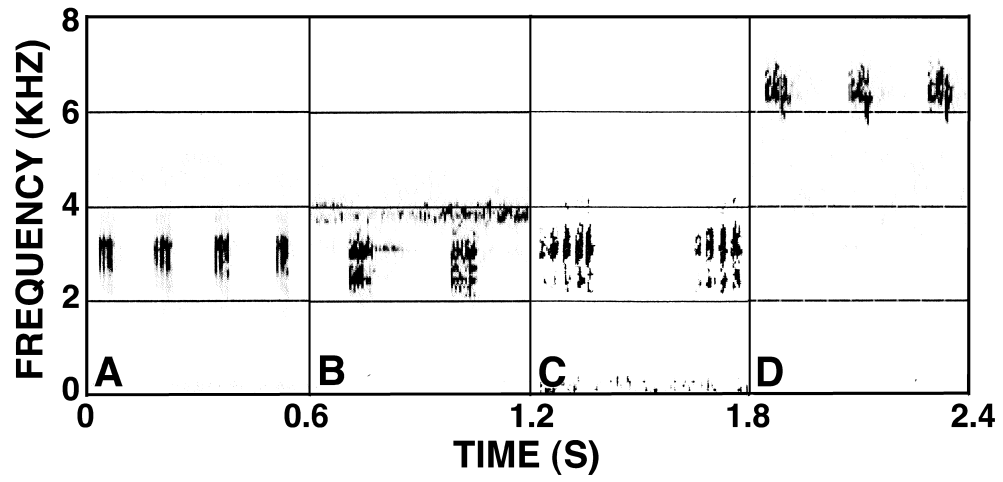

Fig. 3. Sonagrams of advertisement calls of (A) Leptolalax melanoleucus from Khlong Saeng, Surat Thani, (B) L. fuliginosus from Pa Lao U, Prachuap Khiri Khan, (C) L. solus from Hala Bala, Narathiwat, and (D) L. pelodytoides from Doi Suthep, Chiang Mai.

tively. The dominant frequency was 3050-3300 hz, although the band spread over the $2600-3600 \mathrm{hz}$ range. Harmonics were not evident, and frequency and intensity modulations were absent.

Calls recorded at Khao Sok on 19 August 1997 at air temperatures of $24.2-24.3^{\circ} \mathrm{C}$ consisted of one to three notes, each composed of four to eight indistinct pulse groups and lasting 130-260 ms, with a note gap of 220-290 $\mathrm{ms}$. The note repetition rate was 2.1-2.3 per $\mathrm{s}$, and the dominant frequency was $3100-3200 \mathrm{hz}$, although the band spread over the range of $2000-4000 \mathrm{hz}$. Harmonics were unclear, and both frequency and intensity modulation were absent.

\section{Variation}

Individuals of the type series are generally similar in morphology, and vary only slightly. Eye diameter is subequal to snout length in one individual and interorbital distance is slightly greater than upper eyelid width in four individuals. Tibiotarsal articulation of adpressed limb reaches the anterior corner of eye in three individuals. Males from Khlong Saeng and Khao Sok did not differ in SVL or any dimension relative to SVL (Dunn's multiple comparisons test, $P>0.05)$. Some individuals have an elongated white oval spot on the rear surface of thigh at distal one-third.

The temporal characteristics of the call differ between the Khlong Saeng and Khao Sok populations, although the frequency characteristics are similar between them (see above).

\section{Range}

Southern part of the southwestern region to northern part of the southern region of Thailand. Besides the type locality, Khlong Saeng Wildlife Sanctuary, Surat Thani Province, the species was recorded from Muang, Ranong Province; Khao Sok National Park, Surat Thani Province; and Pilok, Thong Pha Pum, Kanchanaburi Province.

\section{Natural History}

At both Khlong Saeng and Khao Sok, males were calling at night on the ground among dead leaves and stones, on slopes $1-10 \mathrm{~m}$ from small streams (width $<2 \mathrm{~m}$ ). Late August seems to be within the breeding season, as evidenced by a female releasing eggs on the night of collection at Khao Sok. In this female, no ova were left inside oviducts, but half-developed ova with a diameter of about $0.65 \mathrm{~mm}$ 
were seen in ovaries. Therefore, multiple breeding with short intervals is expected. Associated species at Khlong Saeng were Bufo parvus, Megophrys sp., Ingerana tasanae, Limnonectes blythi, L. doriae, L. kuhlii, Rana erythraea and $R$. nigrovittata, and those at Khao Sok were Bufo melanostictus, I. tasanae, Megophrys sp., Occidozyga sp., L. doriae, $L$. kuhlii, and $R$. erythraea. At Pilok, no calls were heard in early January, probably because it was very cool. A single individual was found among stones on the bank of a nearly dried small stream (width $<2 \mathrm{~m}$ ).

\section{Leptolalax fuliginosus sp. nov.}

(Fig. 1C, D)

\section{Diagnosis}

A medium-sized form of the genus Leptolalax; male 28.2-30.0 $\mathrm{mm}$ SVL $(n=4)$; tibiotarsal articulation reaching anterior corner of eye; similar to $L$. pelodytoides, but with much lower dominant frequency of advertisement call of 2250 to $2430 \mathrm{hz}$ and dusty ventral side of head and body; similar to $L$. melanoleucus in body shape, but with relatively shorter head, smaller eye and tympanum, and larger inner metatarsal tubercle.

\section{Etymology}

The specific epithet is a Latin word meaning dusty, in reference to the ventral color of the new species as compared to that of $L$. pelodytoides.

\section{Holotype}

KUHE 20174, an adult male from Pa Lao U, Prachuap Khiri Khan Province, Thailand (12³2' N, 99 $\left.{ }^{\circ} 34^{\prime} \mathrm{E}\right)$, collected on 13 December 1995 by Masafumi Matsui and Kunio Araya.

\section{Paratypes}

CUZM (A) 5275, 5276; KUHE 20197 (three males); same data as the holotype.

\section{Description of holotype (measurements in $\mathrm{mm}$ )}

SVL 28.4; habitus moderately slender; head longer (10.7) than broad (9.8); snout rounded, rounded in profile, projecting beyond lower jaw; eye diameter (3.8) slightly smaller than snout length (4.2); canthus distinct, very slightly constricted; lore oblique, slightly concave; nostril lateral, below canthus, distinctly closer to tip of snout than to eye; internarial distance (2.8) narrower than interorbital distance (3.2), latter wider than upper eyelid (2.8); pineal spot absent; tympanum visible, diameter (1.6) less than half that of eye, and separated from eye by two-thirds of tympanic diameter (1.1); vomerine teeth absent; tongue notched, without papillae; a median, subgular vocal sac in the mid-ventral line; vocal openings posterior to rictus, close to eustachian tube openings.

Forelimb slender; fingers slender, unwebbed, first finger slightly shorter than second, latter slightly shorter than fourth; tips slightly swollen; inner palmar tubercle large (1.9), not extending onto first metacarpal and smaller outer palmar tubercle; subarticular tubercles indistinct, replaced by very low callous tissue; nuptial pads absent.

Hindlimb moderately long (45.2); tibia relatively long (13.7), heels overlapping when limbs are held at right angles to body; tibiotarsal articulation of adpressed limb reaching anterior corner of eye; foot (13.2) slightly shorter than tibia; third toe longer than fifth; toe tips similar to those of fingers; webbing confined to bases of toes (Fig. 2B), formula: I $14 / 5-$ $1^{3 / 4}$ II $1 \frac{2 / 3}{3}-2^{1 / 2}$ III $2^{1 / 2}-3^{3 / 4}$ IV $4-2^{2} / 3 \mathrm{~V}$; toes weakly fringed laterally on the first three and base of fourth and fifth toes; subarticular tubercles obscure, but elongate, replaced by low keratinous dermal ridges, a relatively short one on each of second and fifth toes, larger ones on third and fourth toes; inner metatarsal tubercle low, length (1.7) about half of first toe; no outer metatarsal tubercle.

Skin nearly smooth, with a few tubercles of varying sizes above; a low, supratympanic ridge from eye to axilla; sides same as dorsum; chest and abdomen smooth; weak, but large pectoral and weak femoral glands; a small, round, white gland just above axilla; ventrolateral glandular ridges incomplete; skin of gular region not modified.

\section{Color in life}

Light brown dorsally on head and body, scattered with faint dark spots, including a dark, reverse-triangle interorbital spot; posterior half of tympanum masked black; black band below canthus; lips barred with black; sides with several large, dark spots; groin with dark spot not extending onto thigh; limbs marked dorsally with narrow dark brown crossbars, especially narrow on hindlimb; elbow and upper arm without bar dorsally; sides of tibia with black spots, not continuous as bars across dorsal surface; posterior side of thigh dusky, becoming gradually darker toward the rear surface, which is quite dark; an elongated white oval spot on the rear surface of thigh at distal one-third; throat dusky; chest and abdomen white, dusted with fine brown network laterally; ventral surfaces of legs dusky, dotted with light brown; iris reddish orange in upper half, golden reticulated with black in lower half.

\section{Color in preservative}

In preservative, the dorsal coloration has slightly faded to olive brown. Otherwise no obvious changes in color or pattern have occurred. However, eye color has faded and upper and lower halves of iris have become indistinguishable.

\section{Call characteristics}

Calls recorded on 13 December 1995 at air and ground temperatures of 19.3 and $19.6^{\circ} \mathrm{C}$, respectively, consisted of a long series of notes, each composed of six to nine indistinct pulses and lasting 51-80 ms (Fig. 3B). The note-gap and the note-repetition rates varied greatly, 188-402 ms and 2.9 per s, respectively. The frequency range spread over 2060-2810 hz, with the dominant being 2250-2430 hz. Harmonics were unclear, and frequency and intensity modulations were lacking.

\section{Variation}

Individuals of the type series are generally uniform in morphology. In some individuals, eye diameter and snout length are subequal, as are internarial and interorbital distances, and interorbital distance and upper eyelid width, respectively. 


\section{Range}

Known only from the type locality, Pa Lao U, Prachuap Khiri Khan Province, southern part of southwestern Thailand

\section{Natural History}

In mid-December, males were calling at night among stones and litter on the floor of a forest along a stream (width $>5 \mathrm{~m}$ ). Associated species observed were Bufo asper, Amolops panhai, Rana livida, R. nigrovittata, and Taylorana hascheana.

\section{Leptolalax solus sp. nov.}

(Fig. 1E, F)

\section{Diagnosis}

A medium-sized form of the genus Leptolalax, male 27.6 $\mathrm{mm}$ SVL $(\mathrm{n}=1)$; tibiotarsal articulation reaching nostril; more similar to $L$. heteropus than to $L$. pelodytoides, but differing from the former by relatively narrower head, longer hindlimb, and larger inner metatarsal tubercle, as well as by temporal pattern of advertisement call, with successive notes constant in duration.

\section{Etymology}

The specific epithet is a Latin word meaning single or lonely, alluding to the collection of only one male that began calling in captivity, where he could not attract a mate.

\section{Holotype}

KUHE 23261, an adult male from Bala in Hala Bala Wildlife Sanctuary, Narathiwat Province, Thailand $\left(5^{\circ} 49\right.$ 'N, $\left.101^{\circ} 47^{\prime} \mathrm{E}\right)$, collected on 10 January 1997 by Masafumi Matsui.

\section{Description of holotype (measurements in $\mathbf{m m}$ )}

SVL 27.6; habitus moderately slender; head longer (11.7) than broad (9.7); snout rounded, truncate in profile, projecting slightly beyond lower jaw; eye large, diameter (4.3) subequal to snout length (4.2); canthus distinct, straight; lore slightly oblique, slightly concave; nostril lateral, below canthus, distinctly closer to tip of snout than to eye; internarial distance (2.7) narrower than interorbital distance (2.9), latter narrower than upper eyelid (3.1); pineal spot absent; tympanum distinct, diameter (1.8) less than half that of eye, and separated from eye by one-half of tympanic diameter (1.0); vomerine teeth absent; tongue notched, with papillae; a median, subgular vocal sac in the mid-ventral line; vocal openings posterior to rictus, close to eustachian tube openings.

Forelimb slender; fingers slender, unwebbed, first and fourth fingers subequal and longer than second; tips slightly swollen; inner palmar tubercle very large (2.0), not extending onto first metacarpal; smaller outer palmar tubercle; subarticular tubercles indistinct, replaced by long, low callous tissue; nuptial pads absent.

Hindlimb long (47.0); tibia long (14.9), heels overlapping when limbs are held at right angles to body; tibiotarsal articulation of adpressed limb reaching nostril; foot much shorter (12.7) than tibia; third toe longer than fifth; toe tips similar to those of fingers; webbing confined to bases of toes (Fig. $2 \mathrm{C}$ ), formula: I $1 \frac{1}{2}-2+$ II $1 \frac{3 / 4}{4}-3+$ III $2^{3 / 4}-4$ IV $4+-2^{2} / 3 \mathrm{~V}$; toes with lateral fringes; subarticular tubercles obscure, but elon- gate, replaced by large keratinous dermal ridges, a relatively short one on each of second and fifth toes, larger one on third toe, ridge covering entire underside of fourth toe except distal portion; inner metatarsal tubercle distinct, length (1.9) more than half of first toe; no outer metatarsal tubercle.

Skin weakly shagreened, scattered with small tubercles above; top of snout and head without tubercles; a conspicuous, supratympanic ridge from eye to axilla; sides scattered with larger tubercles; chest and abdomen smooth; small, weak pectoral gland and large, elongate femoral gland; no gland above axilla; ventrolateral glandular ridges absent; skin of gular region not modified.

\section{Color in life}

Chocolate-brown dorsally on head and body, with faint interorbital spot of dark brown; tympanum, except for annulus, and inside of supratympanic fold dark brown; dark spots below canthus and sides of snout tip; lips partially barred with dark brown; sides with dark brown flecks; groin without dark spot; limbs marked dorsally with alternating chocolate and dark brown crossbars, the darker ones much narrower; area around the elbow, between upper and lower arms, light brown without dark bars; sides of tibia with black spots, not continuous as bars across dorsal surface; an elongated white oval spot on the rear surface of thigh at distal onethird; throat dusky, dotted with dark brown; chest and abdomen white scattered with dark brown flecks; ventral surfaces of legs dusky, densely scattered with small white spots; iris dark red on upper half, dark brown on lower half.

\section{Color in preservative}

In preservative, the dorsal coloration has slightly faded to maroon. Otherwise no obvious changes in color or pattern have occurred, except for iris, the upper and lower halves of which have become indistinguishable.

\section{Call characteristics}

Calls recorded at air temperatures of $24.2-24.3^{\circ} \mathrm{C}$ (Fig. $3 \mathrm{C})$ consisted of one to three notes. Each note was composed of four to eight indistinct pulse groups and lasted 130-260 ms. The note gap and note repetition rates were 220-290 ms and 2.1-2.3 per s, respectively. The frequency bands spread over the 2000-4000 hz range, and the dominant was 3100-3200 hz. Harmonics were not evident, and frequency modulation and intensity modulation were absent.

\section{Range}

Known only from the type locality, Bala in Hala Bala Wildlife Sanctuary, Narathiwat Province, southernmost Thailand near Malaysian border.

\section{Natural History}

The male holotype was collected at night among rocks $10 \mathrm{~m}$ apart from a large stream (width $>5 \mathrm{~m}$ ) in a rainforest. No calls were heard in the field, but in captivity the male intermittently called from midnight to early morning. Associated species on the night of collection were Bufo parvus, Amolops larutensis, Rana chalconota, and Limnonectes laticeps. 
Table 1. Measurements of 16 characters in species of Leptolalax. SVL $(X \pm 1 S D$, in $\mathrm{mm})$ and medians of ratios $(\mathrm{R})$ of other characters to SVL, followed by ranges in parenthesis. See text for character abbreviations.

\begin{tabular}{|c|c|c|c|c|c|c|c|c|}
\hline Species & Locality & Sex & SVL & $\mathrm{RHL}$ & $\mathrm{RHW}$ & RIND & RIOD & RUEW \\
\hline \multirow[t]{3}{*}{ L. melanoleucus } & Khlong Saeng & $\begin{array}{c}M \\
(N=7)\end{array}$ & $\begin{array}{c}27.6 \pm 0.83 \\
(26.6-28.8)\end{array}$ & $\begin{array}{c}39.9 \\
(37.9-41.1)\end{array}$ & $\begin{array}{c}36.3 \\
(34.0-38.2)\end{array}$ & $\begin{array}{c}10.5 \\
(9.4-11.2)\end{array}$ & $\begin{array}{c}11.5 \\
(10.0-12.8)\end{array}$ & $\begin{array}{c}11.3 \\
(10.8-11.5)\end{array}$ \\
\hline & Khaosok & $\begin{array}{c}M \\
(N=4)\end{array}$ & $\begin{array}{c}27.6 \pm 0.94 \\
(26.9-29.0)\end{array}$ & $\begin{array}{c}40.4 \\
(39.6-41.0)\end{array}$ & $\begin{array}{c}36.7 \\
(36.3-36.9)\end{array}$ & $\begin{array}{c}10.7 \\
(10.3-11.0)\end{array}$ & $\begin{array}{c}10.7 \\
(9.9-11.2)\end{array}$ & $\begin{array}{c}11.3 \\
(10.6-11.7)\end{array}$ \\
\hline & Khaosok & $\begin{array}{c}F \\
(N=1)\end{array}$ & 32.7 & 38.8 & 36.7 & 8.9 & 11.0 & 11.0 \\
\hline L. fuliginosus & Pa Lao U & $\begin{array}{c}M \\
(N=4)\end{array}$ & $\begin{array}{c}28.9 \pm 0.81 \\
(28.2-30.0)\end{array}$ & $\begin{array}{c}38.6 \\
(37.7-39.3)\end{array}$ & $\begin{array}{c}36.1 \\
(34.4-38.0)\end{array}$ & $\begin{array}{c}10.3 \\
(9.0-11.0)\end{array}$ & $\begin{array}{c}10.7 \\
(10.0-11.3)\end{array}$ & $\begin{array}{c}10.1 \\
(9.9-11.0)\end{array}$ \\
\hline L. solus & Hala Bala & $\begin{array}{c}M \\
(N=1)\end{array}$ & 27.6 & 42.4 & 35.1 & 9.8 & 10.5 & 11.2 \\
\hline L. pelodytoides & Karen, Myanmar* & $\begin{array}{c}M \\
(\mathrm{~N}=2)\end{array}$ & $\begin{array}{c}26.7 \\
(24.7-28.6) \\
\end{array}$ & $\begin{array}{c}38.7 \\
(38.1-39.3) \\
\end{array}$ & $\begin{array}{c}36.3 \\
(35.3-37.2) \\
\end{array}$ & $\begin{array}{c}10.3 \\
(10.1-10.5) \\
\end{array}$ & $\begin{array}{c}10.9 \\
(10.5-11.2)\end{array}$ & $\begin{array}{c}10.3 \\
(10.1-10.5) \\
\end{array}$ \\
\hline Species & Locality & Sex & $\mathrm{RSL}$ & REL & RTD & RE-TL & RLAL & RIPTL \\
\hline \multirow[t]{3}{*}{ L. melanoleucus } & Khlong Saeng & $\begin{array}{c}M \\
(N=7)\end{array}$ & $\begin{array}{c}15.0 \\
(14.3-16.1)\end{array}$ & $\begin{array}{c}15.4 \\
(15.0-17.1)\end{array}$ & $\begin{array}{c}7.5 \\
(7.1-8.0)\end{array}$ & $\begin{array}{c}3.5 \\
(2.8-3.8)\end{array}$ & $\begin{array}{c}56.0 \\
(52.1-56.4)\end{array}$ & $\begin{array}{c}5.5 \\
(4.8-6.4)\end{array}$ \\
\hline & Khaosok & $\begin{array}{c}M \\
(\mathrm{~N}=4)\end{array}$ & $\begin{array}{c}15.2 \\
(14.3-15.4)\end{array}$ & $\begin{array}{c}15.3 \\
(14.6-17.2)\end{array}$ & $\begin{array}{c}7.2 \\
(6.9-7.7)\end{array}$ & $\begin{array}{c}3.6 \\
(3.3-3.7)\end{array}$ & $\begin{array}{c}54.9 \\
(52.4-55.8)\end{array}$ & $\begin{array}{c}6.4 \\
(6.2-6.7)\end{array}$ \\
\hline & Khaosok & $\begin{array}{c}F \\
(N=1)\end{array}$ & 14.7 & 14.7 & 8.6 & 3.4 & 55.4 & 5.8 \\
\hline L. fuliginosus & Pa Lao U & $\begin{array}{c}M \\
(N=4)\end{array}$ & $\begin{array}{c}15.0 \\
(14.3-15.6)\end{array}$ & $\begin{array}{c}13.6 \\
(13.4-14.7)\end{array}$ & $\begin{array}{c}6.0 \\
(5.6-6.6)\end{array}$ & $\begin{array}{c}3.9 \\
(3.5-4.1)\end{array}$ & $\begin{array}{c}53.7 \\
(52.3-54.5)\end{array}$ & $\begin{array}{c}6.1 \\
(6.0-6.7)\end{array}$ \\
\hline L. solus & Hala Bala & $\begin{array}{c}M \\
(N=1)\end{array}$ & 15.2 & 15.6 & 6.5 & 3.6 & 54.0 & 7.2 \\
\hline L. pelodytoides & Karen, Myanmar* & $\begin{array}{c}\mathrm{M} \\
(\mathrm{N}=2) \\
\end{array}$ & 15.4 & $\begin{array}{c}14.8 \\
(13.8-15.8) \\
\end{array}$ & $\begin{array}{c}6.8 \\
(6.6-6.9) \\
\end{array}$ & 4.0 & $\begin{array}{c}51.8 \\
(51.0-52.6) \\
\end{array}$ & \\
\hline Species & Locality & Sex & RTL & RFL & RHLL & RIMTL & & \\
\hline \multirow[t]{3}{*}{ L. melanoleucus } & Khlong Saeng & $\begin{array}{c}M \\
(N=7)\end{array}$ & $\begin{array}{c}48.9 \\
(45.8-51.1)\end{array}$ & $\begin{array}{c}44.6 \\
(39.9-45.1)\end{array}$ & $\begin{array}{c}162.5 \\
(151.7-169.2)\end{array}$ & $\begin{array}{c}4.5 \\
(4.2-5.4)\end{array}$ & & \\
\hline & Khaosok & $\begin{array}{c}M \\
(N=4)\end{array}$ & $\begin{array}{c}49.7 \\
(48.0-51.3)\end{array}$ & $\begin{array}{c}44.2 \\
(44.0-45.7)\end{array}$ & $\begin{array}{c}161.8 \\
(158.6-166.9)\end{array}$ & $\begin{array}{c}5.5 \\
(5.2-6.2)\end{array}$ & & \\
\hline & Khaosok & $\begin{array}{c}\mathrm{F} \\
(\mathrm{N}=1)\end{array}$ & 48.3 & 44.6 & 160.6 & 4.9 & & \\
\hline L. fuliginosus & Pa Lao U & $\begin{array}{c}M \\
(\mathrm{~N}=4)\end{array}$ & $\begin{array}{c}48.3 \\
(46.7-50.4)\end{array}$ & $\begin{array}{c}46.0 \\
(44.7-48.6)\end{array}$ & $\begin{array}{c}159.4 \\
(153.7-177.2)\end{array}$ & $\begin{array}{c}5.6 \\
(5.3-6.0)\end{array}$ & & \\
\hline L. solus & Hala Bala & $\begin{array}{c}M \\
(N=1)\end{array}$ & 54.0 & 46.0 & 170.3 & 6.9 & & \\
\hline L. pelodytoides & Karen, Myanmar* & $\begin{array}{c}M \\
(N=2)\end{array}$ & $\begin{array}{c}49.7 \\
(49.7-49.8)\end{array}$ & $\begin{array}{c}49.9 \\
(49.4-50.3) \\
\end{array}$ & $\begin{array}{c}165.3 \\
(165.0-165.6)\end{array}$ & 5.3 & & \\
\hline
\end{tabular}

${ }^{*}$ Specimens stored in MSNG and BM.

\section{DISCUSSION}

\section{Acoustic comparisons}

Because males of most anuran species utilize speciesspecific acoustic signals for attracting conspecific females, call characteristics play a large role in taxonomic studies (e.g., Matsui et al., 1986; Matsui, 1997). In L. melanoleucus described here, the temporal characteristics of calls differed between two different populations, but the frequency characteristics were nearly the same. The two populations are treated herein as a single species because of their close morphological similarity, although the possibility is not rejected that the temporal differences observed between their calls actually indicate substantial genetic differentiation. In order to assess this, comparisons of the two populations by other methods such as biochemical ones are necessary. Among Leptolalax species, however, frequency properties usually differ more than temporal ones (Matsui, 1997, unpublished).

All known Bornean members of Leptolalax for which calls have been reported [L. arayai Matsui, 1997; L. dringi Dubois, 1987; L. gracilis (Günther, 1872); L. hamidi Matsui, 1997; L. pictus Malkmus, 1992] markedly differ acoustically from the continental species, including the three new species (Matsui, 1997, unpublished; Malkmus et al., 2002). The call of the remaining Bornean species, L. maurus Inger, Lakim, Biun, and Yambun, 1997, is unknown.

Among the three new species, $L$. fuliginosus superficially resembles L. pelodytoides (Boulenger, 1893) from China to northern Thailand. However, the dominant frequency in the calls of $L$. pelodytoides recorded at Doi Suthep, Chiang Mai, at an air temperature of $22.7 \mathrm{C}$ spread over 6350-6550 hz (Matsui, unpublished; Fig. 3D), and is thus drastically different from that of $L$. fuliginosus, as well 
as of the other two new species $(2250-3300 \mathrm{hz})$. This difference is not attributable to differences in ambient temperature or body size. Similarly, L. oshanensis (Liu, 1950) from Sichuan and L. liui Fei and Ye in Fei, Ye, and Huang (1991) from Hong Kong, respectively 4000-5000 and 4500-5500 $\mathrm{hz}$ in dominant frequency (Matsui, unpublished), are distinct from the three new species in this character.

Leptolalax solus superficially resembles $L$. heteropus (Boulenger, 1900) from the Malay Peninsula more than $L$. pelodytoides. As was shown by Matsui (1997), however, calls in $L$. heteropus consist of three notes whose lengths are not constant (vs. nearly constant in L. solus). Also, the first note lasts $80 \mathrm{~ms}$, and the second and third notes are shorter, each lasting $28 \mathrm{~ms}$ in $L$. heteropus, whereas all notes last $130-260 \mathrm{~ms}$ in L. solus. The dominant frequency in calls of the former is $2833 \mathrm{hz}$ in the first note, but is slightly lower in subsequent notes (vs. 3100-3200 hz in all notes in $L$. solus). Thus, the two species decidedly differ in acoustic characteristics.

\section{Morphological comparisons}

Leptolalax pelodytoides differs from the three new species not only in acoustic traits, but also in the completely or nearly immaculate venter and the better developed lateral fringes along the toes (Matsui's observation of type series). Likewise, $L$. oshanensis and $L$. liui have the ventral surface of the body unmarked or with only small, light gray spots (Fei, 1991; Matsui, unpublished data). Thus, they clearly differ from L. melanoleucus, which has a venter mottled with black and white. Leptolalax fuliginosus resembles some individuals of $L$. oshanensis and $L$. liui in having a dusty venter. However, $L$. fuliginosus differs from $L$. oshanensis in having webbing among the toes [nearly lacking in L. oshanensis (Inger et al., 1990)], and from L. liui in having a slightly larger body [male $S V L=28.2-30.0 \mathrm{~mm}$, as compared to 23$28.7 \mathrm{~mm}$ in L. liui (Fei et al., 1991)] and lacking the wide lateral fringe on the toes [present in L. liui (Fei et al., 1991)]

Leptolalax solus superficially resembles $L$. heteropus, but differs from it in details of morphology; males of topotypic $L$. heteropus have SVL 24.6-26.0 mm (vs. $27.6 \mathrm{~mm}$ in L. solus), HW 36-41\% (vs. 35\%), TL 50-53\% (vs. 54\%), FL 40-46\% (vs. 46\%), and IMTL 3.6-4.4\% (vs. 6.9\%), all relative to SVL (Matsui, unpublished). Although Berry (1975) gave larger SVL (33-35 $\mathrm{mm}$ ) for $L$. heteropus, she did not refer to the sex, and the values may have included females.

Of the species for which acoustic information is lacking, Bornean L. maurus has a unique dark venter (Inger et al., 1997; Malkmus et al., 2002), and is thus distinct from the three new species. Of the continental species, L. tuberosus Inger, Orlov, and Darevsky, 1999 from Vietnam lacks a clearly visible tympanum (Matsui's own observation of type series), unlike all other congeners, including the three new species.

The following species are distinctly larger than the three new species (SVL $=26.6-30.0 \mathrm{~mm}$ in males): $L$. bourreti Dubois, 1983 (SVL=29.3-36.2 mm in males; Matsui's own observations), L. sungi Lathrop, Murphy, Orlov, and Ho, 1998 (SVL=48.3-52.7 mm in males; Lathrop et al., 1998), and L. nahangensis Lathrop, Murphy, Orlov, and Ho, 1998 (SVL=40.8 $\mathrm{mm}$ in unique male holotype; Lathrop et al., 1998), all from Vietnam; and L. kajangensis Grismer, Gris- mer, and Youmans, 2004 from Malaysia (SVL=34.0-35.0 $\mathrm{mm}$ in males). In contrast, L. pluvialis Ohler, Marquis, Swan, and Grosjean, 2000 from Vietnam is much smaller than the three new species (male SVL=21.3-22.3 mm; Ohler et al., 2000). Of these, L. sungi, L. nahangensis, and L. kajangensis have the ventral surface of body unspotted or only with small, light gray spots (Lathrop et al., 1998; Grismer et al., 2004), and L. pluvialis has a gray ventrum with dark gray marbling (Matsui's own observation of the type series). Thus, they are more similar to $L$. fuliginosus and $L$. solus than to L. melanoleucus (see comments in the first paragraph of this subsection). However, all of them are quite different from the three new species in body size, as noted above. In addition, L. pluvialis lacks toe webbing, unlike the three new species. Although L. bourreti slightly overlaps in body size, it has no marking on the ventrum, unlike the three new species.

Two Chinese species are reported to have a maculate venter like $L$. melanoleucus, and unlike $L$. fuliginosus or $L$. solus. In L. alpinus Fei, Ye, and Huang, 1991, the venter is more or less dark spotted, but the distribution of dark markings is much more limited than in L. melanoleucus, judging from Fig. 33 in Plate VI of Fei et al. (2005). Additionally, $L$. alpinus is slightly smaller in male body size (male $S V L=24.0-26.4 \mathrm{~mm}$; Fei et al., 1991) than the three new species. Leptolalax ventripunctatus Fei, Ye, and $\mathrm{Li}$ in Fei, Ye, and Huang (1991) also resembles L. melanoleucus both in body size (male SVL about $26.5 \mathrm{~mm}$ : Fei, 1999) and the presence of clear, dark markings ventrally (Fei, 1991). However, the pattern of dark markings in $L$. ventripunctatus is again quite different from that of $L$. melanoleucus: in $L$. ventripunctatus, the dark area is restricted to the chest and abdomen, not extending to the throat (see Fig. 31 in Plate $\mathrm{VI}$ of Fei et al., 2005). Furthermore, L. ventripunctatus has longitudinal skin ridges on the dorsum (Fei, 1999).

\section{Taxonomic diversity and biogeography}

In a recent publication on the amphibian fauna of Thailand, Chan-ard (2003) listed four species of Leptolalax ( $L$. bourreti, L. gracilis, L. heteropus, and L. pelodytoides) from this country. However, because this work is an illustrated guidebook, sources of data or the bases for identification are not provided.

As noted in the Introduction, another species, L. minimum, is described from Doi Suthep (Taylor, 1962). Dubois (1981), however, synonymized this species with Chinese $L$. oshanensis, and the latter with $L$. pelodytoides (Dubois, 1983). Although Inger et al. (1990) retained L. oshanensis as valid, they regarded it as a subspecies of $L$. pelodytoides and considered its range as restricted to southwestern China. Thus, the exact status of $L$. minimum is unclear, and the name is now subsumed under the name $L$. pelodytoides.

Leptolalax pelodytoides (including L. minimum) is currently believed to occur in a very wide range from Myanmar (Boulenger, 1893) through Thailand (Taylor, 1962) and Vietnam (Inger et al., 1999) to southern China (Fei et al., 2005), and actually exhibits geographical variation even within Thailand (Matsui, unpublished data). Chan-ard (2003) listed $L$. bourreti from the distributional range of $L$. pelodytoides, but the species identification is dubious (see above). His action may also be related to the complex nature of $L$. pel- 
odytoides and, thus, further work is needed on this species. Even so, the acoustic characteristics of Thai populations of L. pelodytoides are basically similar, and are quite distinct from those of the three new species, as discussed above.

Leptolalax solus is geographically and morphologically close to $L$. heteropus. An individual of $L$. heteropus shown by Chan-ard (2003) in a photograph undoubtedly looks more like $L$. heteropus than $L$. solus, and the body size given therein $(33-35 \mathrm{~mm}$ ) is larger than that of $L$. solus. However, the origin of the individual photographed is unclear, and the body size coincides with that given by Berry (1975). Thus, the form from Thailand identified as L. heteropus by Chan-ard (2003), if it exists, may actually represent L. solus. Similarly, from the map in Chan-ard (2003), L. gracilis (not illustrated in a photograph) may actually be $L$. melanoleucus, because the body size documented (32-51 mm) again completely matches that of $L$. gracilis given by Berry (1975). In my opinion, L. gracilis is endemic to Borneo, and records from the Malay Peninsula (Berry, 1975; Grandison, 1972) may represent another, undescribed species.

The pattern of distribution within Thailand of the three new species, together with that of $L$. pelodytoides, is interesting (Fig. 4). Along the Myanmar border, L. pelodytoides extends from the northern and northeastern regions southward to Erawan, Kanchanaburi. The known distributional range of $L$. melanoleucus is disjunct, with its northern limit (Pilok, Kanchanaburi) extending slightly northward of the southern limit of $L$. pelodytoides. The southern range of $L$. melanoleucus in Muang (Ranong) and in Khlong Saeng and Khao Sok (Surat Thani) extends slightly south of the Isthmus of Kra. Between these two ranges of $L$. melanoleucus, L. fuliginosus occurs in Pa Lao U (Prachuap Khiri Khan), as if displacing northern L. pelodytoides. In the south of Surat Thani, L. solus occurs in the extreme south of Hala Bala, Narathiwat. No Leptolalax species has been found in between.

To date, no sympatric occurrence of two or more species of the genus has ever been detected, but the southern limit of $L$. pelodytoides and the northern limit of $L$. melanoleucus are not distant. These two species have different calls and could co-occur through pre-mating reproductive isolation. Thus, their sympatric occurrence is not unexpected. A ranid, Amolops panhai, has a range similar to that of $L$. melanoleucus (Pilok and Ranong), and like L. fuliginosus is also found in Pa Lao $\mathrm{U}$ (Matsui and Nabhitabhata, 2006). Therefore, it is also possible that $L$. melanoleucus has a more continuous range, overlapping the range of $L$. fuliginosus. Because these species have similar calls, at least to human ear, whether or not they can co-exist is an interesting problem.

This complicated pattern of distribution should be more accurately documented by adding locality records of correctly identified specimens. Further field surveys in Thailand, Myanmar, and Malaysia, as well as re-examination of specimens on which the records of each species were based by previous authors, are badly needed in order to understand pattern of distribution and to infer the evolutionary history of the genus. Even so, the discovery of two of the three new species ( $L$. melanoleucus and L. fuliginosus) provides another example of occurrence of distinct species of congeners between northern and southern regions around

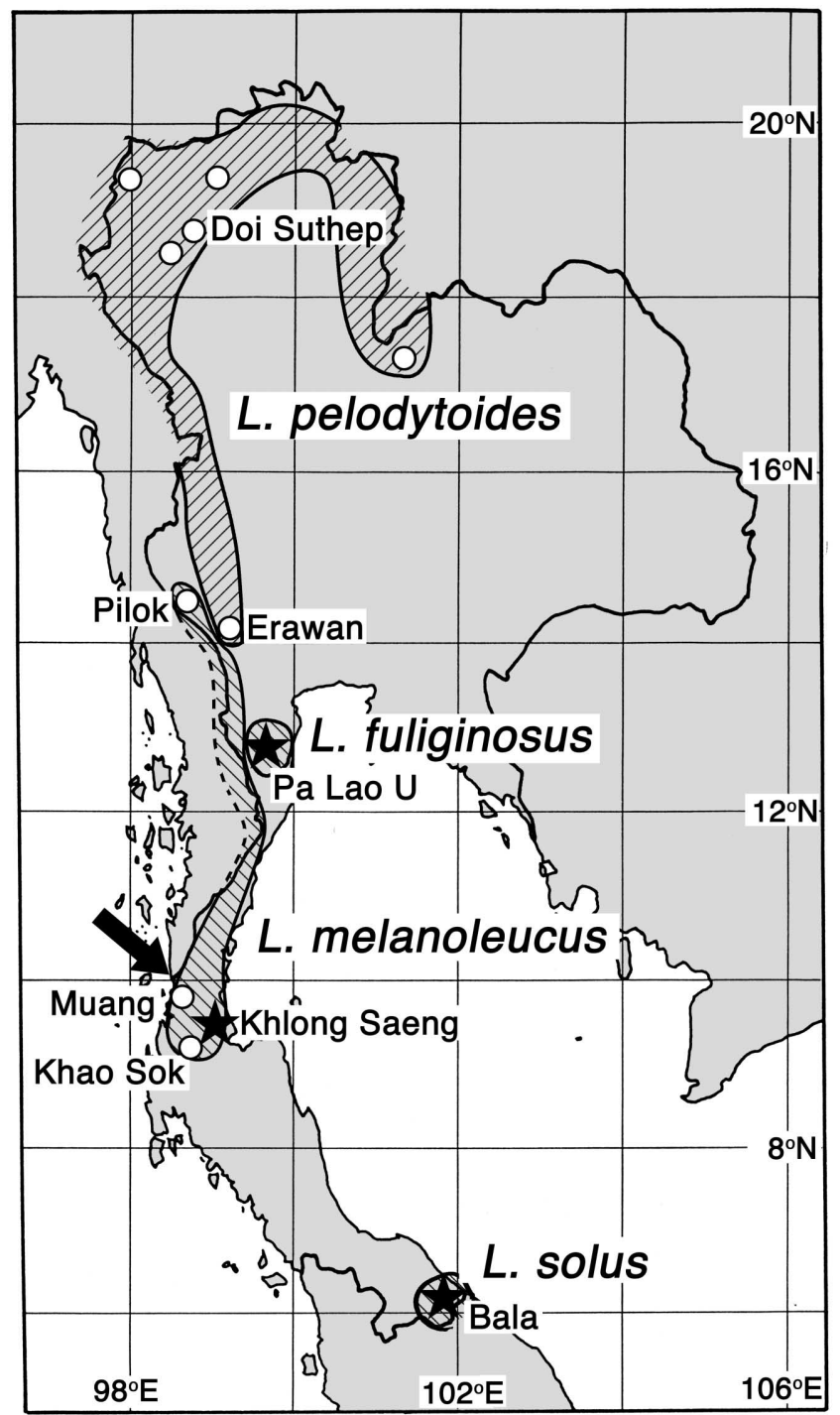

Fig. 4. Map of Thailand showing the known distributions of four species of Leptolalax (open circles) and the type localities of the three new species (closed stars). Black arrow indicates the Isthmus of Kra.

the Isthmus of Kra, the base of peninsular Thailand (Ansonia kraensis: Matsui et al., 2005; Amolops panhai: Matsui and Nabhitabhata, 2006).

\section{ACKNOWLEDGMENTS}

K. Araya, T. Hikida, M. Honda, W. Khonsue, J. Nabitabhata, H. Ota, S. Panha, T. Sugahara, and M. Toda greatly helped me in the field. The National Research Council of Thailand and the Royal Forest Department of Thailand granted permission for fieldwork in Thailand. I thank S. Tunhikorn for help in obtaining permission. I am grateful to R. F. Inger (FMNH), C. McCarthy and B. T. Clarke (BM), G. Doria (MBG), A. Ohler and A. Dubois (MNHNP), R. Günther and U. Manthey (ZMB), P. Y. Imbun and M. B. Lakim (SP), and M. Maryati and A. Sudin (UMS) for allowing me to examine specimens under their care. O. S. G. Pauwels, C. Chimsunchart, and M. Sumontha allowed examination of a specimen they collected. A. Tominaga prepared figures. This study was supported by grants from The Monbusho (Field Research, Nos. 06041066, 08041144, 
10041166, and 15370038) and TJTTP-OECF.

\section{REFERENCES}

Berry PY (1975) The Amphibian Fauna of Peninsular Malaysia. Tropical Press, Kuala Lumpur

Boulenger GA (1893) Viaggio di Leonardo Fea in Birmania e regioni vicine LII. Concluding report on the reptiles and batrachians obtained in Burma by Signor L. Fea, dealing with the collection made in Pegu and the Karin Hills in 1887-88. Ann Mus Civ Stor Nat Genova Ser 2 13: 304-347

Chan-ard T (2003) A Photographic Guide to Amphibians in Thailand. Darnsutha Press, Bangkok

Dubois A (1981) Notes sur la systematique et la repartition des amphibien anoures de Chine et des regions avoisantes. V. Megophrys oshanensis Liu, 1950 et Leptobrachium minimum Taylor, 1962. Bull Mens Soc Linn Lyon 50: 182-192

Dubois A (1983) Note preliminaire sur le genre Leptolalax Dubois, 1980 (Amphibiens, Anures), avec diagnose d'une espèce nouvelle du Vietnam. Alytes 2: 147-153

Dubois A [1987 (1986)] Miscellanea taxinomica [sic] batrachologica (I). Alytes 5: 7-95

Fei L (Ed) (1999) Atlas of Amphibians of China. Henan Science and Technology Press, Zhengzhow

Fei L, Ye CY (1992) Comments on the taxonomy of pelobatid toads of the genus Leptolalax (Carpophrys) with description of a new species. Acta Zool Sinica 38: 245-253

Fei, L, Ye CY, Huang YZ [1991 (1990)] Key to Chinese Amphibia. Chongqing Branch Science and Technology Literature Press, Chongqing

Fei L, Ye CY, Jiang JP, Xi F, Huang YZ (2005) An Illustrated Key to Chinese Amphibians. Sichuan Publishing Group and Sichuan Publishing House of Science and Technology, Chengdu

Grandison AGC (1972) The Gunong Benom Expedition, 1967. 5. Reptiles and amphibians of Gunong Benom with a description of a new species of Macrocalamus. Bull Br Mus Nat Hist (Zool) 23: $45-101$

Grismer LL, Grismer JL, Youmans TM (2004) A new species of Leptolalax (Anura: Megophryidae) from Pulau Tioman, west Malaysia. Asiatic Herpetol Res 10: 8-11

Inger RF, Zhao EM, Shaffer HB, Wu GF (1990) Report on a collection of amphibians and reptiles from Sichuan, China. Fieldiana Zool New Ser 58: 1-24
Inger RF, Lakim M, Biun A, Yambun P (1997) A new species of Leptolalax (Anura: Megophryidae) from Borneo. Asiatic Herpetol Res 7: 48-50

Inger RF, Orlov N, Darevsky I (1999) Frogs of Vietnam: A report on new collections. Fieldiana Zool New Ser 92: 1-46

Lathrop A, Murphy RW, Orlov N, Ho CT (1998) Two new species of Leptolalax (Anura: Megophryidae) from northern Vietnam. Amphibia-Reptilia 19: 253-267

Malkmus R (1992) Leptolalax pictus sp. n. (Anura: Pelobatidae) vom Mount Kinabalu/Nord-Borneo. Sauria Berlin 14: 3-6

Malkmus R, Riede K (1993) Nachtrag zu Leptolalax pictus Malkmus, 1992 (Anura: Pelobatidae). Sauria Berlin 15: 7-9

Malkmus R, Manthey U, Vogel G, Hoffman P, Kosuch J (2002) Amphibians and Reptiles of Mount Kinabalu (North Borneo). ARG Ganter Verlag Kommanditgesellschaft, Ruggell

Matsui M (1984) Morphometric variation analyses and revision of the Japanese toads (Genus Bufo, Bufonidae). Contrib Biol Lab Kyoto Univ 26: 209-428

Matsui M (1997) Call characteristics of Malaysian Leptolalax with a description of two new species (Anura: Pelobatidae). Copeia 1997: 158-165

Matsui M, Nabhitabhata J (2006) A new species of Amolops from Thailand (Amphibia, Anura, Ranidae). Zool Sci 23: 727-732

Matsui M, Seto T, Utsunomiya T (1986) Acoustic and karyotypic evidence for specific separation of Polypedates megacephalus from $P$. leucomystax. J Herpetol 20: 483-489

Matsui M, Khonsue W, Nabhitabhata J (2005) A new Ansonia from Isthmus of Kra, Thailand (Amphibia, Anura, Bufonidae). Zool Sci 22: 809-814

Nabhitabhata J, Chan-ard T, Chuaynkern Y (2000) Checklist of Amphibians and Reptiles in Thailand. Office Environ Policy Plan, Bangkok

Ohler A, Marquis O, Swan S, Grosjean S (2000) Amphibian biodiversity of Hoang Lien Nature Reserve (Lao Cai Province, northern Vietnam) with description of two new species. Herpetozoa 13: $71-87$

Savage JM (1975) Systematics and distribution of the Mexican and Central American stream frogs related to Eleutherodactylus rugulosus. Copeia 1975: 254-306

Taylor EH (1962) The amphibian fauna of Thailand. Univ Kansas Sci Bull 43: 265-599

(Received February 6, 2006 / Accepted April 20, 2006)

Appendix 1. Specimens of Leptolalax examined for comparisons. For museum acronyms, see text.

L. arayai Matsui, 1997: SP 01804 (holotype), BORNEENSIS 22623, 22624, 22692, 22693, 22739-22747, 22783 (topotypes), 22903,22931 ; L. bourreti Dubois, 1983: MNHN 1938.0094 (holotype), 1938.0093, 1938.0095 (paratypes), 1999.5665, 1999.5667-1999.5669, 1999.56711999.5673; L. dringi Dubois, 1987: BORNEENSIS 22681-22691, 22701, 22748, 22749, 22756, 22760, 22784-22786, 22980, 23029, 23034, 23482; L. gracilis (Günther, 1872): BM 1944.2.25.5 (=92.2.19.35, holotype), KUHE 10634-10637, 10717, 12019, 12020, 12023 (topotypes), 17133, 17136, 17168, 17183, 17273, 17283, 17665; L. hamidi Matsui, 1997: KUHE 17546 (holotype), 17374, 17545 (paratypes); L. heteropus (Boulenger, 1900): KUHE 15432, 15433, 15485-15490 (topotypes); L. liui Fei and Ye In Fei, Ye, and Huang, 1991: KUHE 21705; L. minimum Taylor, 1962: FMNH 178229 (paratype); L. maurus Inger, Lakim, Biun, and Yambun, 1997: SP 2531 (holotype); L. pelodytoides (Boulenger, 1893): MSNG CE 29845A (lectotype), 29845B (paralectotype), BM 1947.2.25.14 (=93.10.9.46, paralectotype), ZMB 11588, KUHE 19113, 19130-19134, 19200, 19201, 19210, 19220-19224, 19229-19231, 19249, 19250, 19255-19262, 19809, 19815, 19816, 19993-19998, 20004-20016, 20024-20027, 20039-20043, 23733; L. pictus Malkmus, 1992: BORNEENSIS 22837-22839, 22859, 22864, 22894 (topotypes), 8871-8876, 12422, 12426, 12602, 12635, 12697, 22350, 22351, 22967, 22995, 23050, 23303, 23304, 23308, 23317, 23483, 23484, 23495-23498; L. pluvialis Ohler, Marquis, Swan, and Grosjean, 2000: MNHN 1999.5675 (holotype), 1999.5674, 1999.5676 (paratypes); L. tuberosus Inger, Orlov, and Darevsky, 1999: FMNH 252846, 252851, 252854, 252856, 252859 (paratypes). 